\title{
Much more than talking: An emergent bilingual learner's interactions in a New Zealand early childhood centre
}

\author{
Madoka Takemoto, Carolyn Tait, and Margaret Gleeson \\ School of Education, Victoria University of Wellington
}

\begin{abstract}
This qualitative study uses a sociocultural perspective to examine the interactions of a child from a Chinese speaking home with his peers in a New Zealand early childhood centre. He was 3 years 3 months at the time of data collection. Data were gathered in three five-minute video recordings taken over a period of three weeks during free play in a group of children. Deductive coding revealed themes of active interaction, emotion, influence, and verbal interaction. The analysis, using Hawkins' (2004) perspectives of learning environments, indicated that the use of culturally inclusive resources during free play allowed the children to create a community of learners and scaffold social and linguistic learning. The teacher chose to observe these interactions. One implication is that free play in an early childhood education environment without direct teacher guidance can be an important part of facilitating the learning of emergent bilingual children.
\end{abstract}

Keywords: emergent bilingual, interaction, free play, linguistic learning

\section{Introduction}

Our qualitative study offers an understanding of an emergent bilingual child's peer interaction in a New Zealand kindergarten. New Zealand is a multicultural country, comprising people from diverse ethnic groups and diverse language backgrounds (Howard, 2009). The number of people born overseas has significantly increased in the past ten years. Asian and Pacific born children make up the highest proportion of children coming from non-English speaking backgrounds (NESB) (Ministry of Social Development, 2016). These NESB learners may change the composition of New Zealand schools and early childhood education (ECE). Despite this, there are few studies of how Asian children interact with other children in ECE settings (Castro, 2014). Existing studies suggest that if NESB children are active members of a learning community, they are likely to positively influence other children in their behaviour and social skills (Cho, 2012; Gottfried, 2014).

The New Zealand ECE curriculum document, Te Whāriki (Ministry of Education, 1996, 2017), is underpinned by Vygotsky's (1978) Sociocultural Theory (SCT) which strongly values children's learning through interaction with people and the environment (Carr, 2009). Children are expected to develop through holistic learning that encompasses physical, emotional, cognitive, social, and spiritual domains. Learning experiences through interaction with peers are valued as contributing to emotional well-being and learning. Interaction is a positive learning disposition regarded as essential to healthy development (Lee \& Carr, 2012). 


\section{Theoretical approaches: A sociocultural perspective}

Vygotsky (1978) argues that children can learn in their zone of proximal development (ZPD) provided they have support from more skilled people including adults, older children, or children with more capability and experience. Learning is not an individual and independent cognitive process but is embedded in the social context where co-construction of knowledge and learning occur through interaction with others.

Since learning occurs in a social context, children are affected by their learning environment (Walqui, 2006; Wells, 2009). Wells contends that the nature of their environment, adults' knowledge of children, relationships, and the relevance of the learning make a difference. In addition, Barnard (2009) and Davies (2004) emphasise that it is important for children to feel accepted and gain a sense of belonging to a particular community of practice.

\section{Community of practice / community of learners}

Drawing on SCT, the concept community of practice was first introduced by Lave and Wenger (1991) to explain situated learning, where knowledge and skills are co-constructed by a group of individuals having a common enterprise or sharing resources. Wenger (1998) identifies engagement, imagination and alignment of resources and practices as modes of belonging that contribute to learning within the community of practice. Although alignment may not be evident in an ECE context especially when children are not directly interacting with each other (Broadhead, 2009), children may often develop a sense of belonging to their group when they play with or near others (Ministry of Education, 1996). While children are interacting with each other, they may develop various emotions and this may influence both their social and cognitive development (Horwitz, 2010; Swain, 2013). The co-construction of emotion may occur as a group of learners develop emotional intersubjectivities within their community of learners (Imai, 2010; Swain, 2013).

Similarly, community of learners describes the shared social environment where children are engaged in learning (MacNaughton \& Williams, 2008) within a caring community where warm relationships, respect, and reciprocal learning provide a foundation for cognitive and emotional development (Bredekamp, 2014). Peer tutoring occurs when children who are more capable in one area support other children to develop their knowledge, whereas peer collaboration refers to children with similar capabilities learning from each other and co-constructing knowledge (Smith, 2012).

Social competence is culturally bound (Han, 2009; Purcell-Gates, Melzi, Najafi, \& Orellana, 2011). When a community of practice is dominated by a majority's cultural values and practices, children from a minority cultural background may have difficulty adjusting (Barnard, 2009). In New Zealand, when NESB children join an education setting where English is the dominant language, they need to not only learn English, but also classroom expectations of interaction at the setting, such as turn taking, proximity, tone and volume of voice, as well as when to sit still or raise their hand during whole group time.

\section{Scaffolding}

Scaffolding is widely acknowledged as an effective way of supporting children within their ZPD (Hammond \& Gibbons, 2006; Walqui, 2006). Through scaffolding from others within his/her ZPD, a child is believed to be able to do what he/she cannot do otherwise (Hammond 
\& Gibbons, 2006). Pedagogical scaffolding is likened to a temporary structure which can be removed once children can manage their task without it (Gibbons, 2015). Hammond and Gibbons also note that since children's ZPD changes as a result of co-constructing and developing knowledge with others, supporting children in a timely manner is essential. Accordingly, contingent scaffolding is "by definition, unplanned, something that happens on the spot when a learner says or does something that foreshadows a new development" (Walqui \& van Lier, 2010, p. 24). Walqui (2006) argues that collaboration through interaction produces collective scaffolding.

Successful scaffolding is accomplished only when children work with others to solve the problem at hand, otherwise they will not manage to reproduce the same result when scaffolding is removed (Wood, Bruner, \& Ross, 1976). It is critical to provide just enough support only when necessary so as not to diminish children's motivation for managing challenging tasks on their own (Hammond \& Gibbons, 2006). Learning can also be considered to be taking place in the ZPD of young children when a child observes and copies practices of their peers even when s/he is engaging in parallel play (Hawkins, 2004).

\section{Children's play and interaction within ECE settings}

Children learn and develop through interaction with people and their environment while playing (Jamison, Forston \& Stanton-Chapman, 2012). However, a significant decrease in the time allowed for children's active free play time has been reported internationally (Bodrova, 2008; Ebbeck \& Waniganayake, 2010; Nicolopoulou, 2010). This is partly caused by increased use of digital media and automobile transportation, together with marketing forces, and pressure from the school sector to promote academic learning such as literacy or numeracy. Some teachers may feel obliged to justify children's play to parents and stakeholders as learning experiences that prepare children for future school learning. Play enhances children's development within the physical, social, spiritual and emotional domains, all of which form sound dispositions for children's learning (Lee \& Carr, 2012).

\section{Children's interaction in their play time}

Social interaction is regarded as the heart of learning from a SCT perspective (Vygotsky, 1978). Interaction involves giving and receiving information and responding to feelings from others, which may happen while observing peers, and thereby "accumulating and accommodating their prior conceptions" (Lim, 2012, p. 401). A joint focus of attention can increase children's interaction during play (Jamison et al., 2012). By sharing a common focus, children start understanding others' intentions in the play and this may extend the collective imagining of the play. Children often move flexibly among cooperative, associative and parallel play (Fleer, 2013).

When children want to share the type of play or the rules in a situation, they sometimes signal others by using cues, termed play meta-communication, to announce the mode of communication. This includes explaining the situation during dramatic play, such as making a dramatic movement to show the start of imaginary play (Fleer, 2013). Children may spend most of their time in silence when they are engaged in their play (Hojnoski, Margulies, Amberly, Bose-Deakins, \& Sumara, 2008). Despite the silence, even in parallel play, active coconstruction of knowledge and skills can be observed as children gain inspiration and copy each other (Lim, 2012). 


\section{The teachers' role in children's play and interaction}

ECE teachers can enhance children's interaction through a carefully planned environment and curriculum that elicits different language forms (Smith, 2012). They may also provide timely scaffolding so that children stay focused and develop their play. Van Hoorn, Nourot, Scales, and Alward (2011) argue that teachers have a central role in children's play as they carefully orchestrate a play-centred curriculum to guide children to switch flexibly between emergent teacher-guided learning experiences and free play.

In order to encourage children's initiative in their play, White et al. (2010) suggest teachers should refrain from interfering with play, allowing children to take the lead in their play. Otherwise, the presence of adults may hinder children's active interaction with others (Liu, Lin, Liou, Feng, \& Hou, 2013). Children may become reliant on teachers and be unable to act independently. This suggests that teachers should strive to find a balance between becoming involved in children's play (Van Hoorn et al., 2011) and observing them without involvement. Teachers may be able to balance being present with being unobtrusive if they engage in a different task near where children are playing (Hojnoski et al., 2008). This will allow them to encourage children's interaction by being readily available when necessary.

Sometimes it may be challenging for teachers to just wait and observe the children's own problem-solving methods, especially when children are facing conflicts with others (O'Connor \& Angus, 2014). While teachers must interfere to keep the children safe from physical and emotional harm, what can look like inappropriate fighting may be revealed as playful negotiation once teachers deepen their understanding of each child and combinations of children (Broadhead, 2009). When teachers step back, they can observe and analyse peer interactions.

\section{Implications for NESB children}

Farnsworth (2012) notes that NESB children should be included in the regular learning environment to develop their relationships with others. This interaction is critical for social learning and a sense of belonging. Ample interaction was found to be effective in accelerating second language acquisition, particularly when NESB children may have little English exposure in the environment outside ECE centres (Aukrust \& Rydland, 2011).

When NESB children first join an English language environment, they often go through a silent period where they do not speak even when they are already capable of speaking some English (Krashen, 1981). Despite appearing withdrawn, children in this silent period may be actively engaged in learning by very quietly imitating others, repeating their learning and practising through silent talk (Iddings \& Jang, 2008).

It is an advantage to emergent bilinguals to maintain both languages because the knowledge and skills from their home culture and language can support children's learning in a new language environment (Castro, Paez, Dickinson, \& Frede, 2011). Bilingual children can apply knowledge acquired in their first language to English and teachers may need to pay careful attention to children's knowledge developed at home and in the home language to build on it in the English-speaking ECE centre environment (Akbulut, 2007). The role of the teacher has a significant impact since language learning is dependent on social interaction (Gibbons, 2015).

Language users choose from multiple social languages to adapt to the context, the speakers' language proficiency, and their level of comprehension (Hawkins, 2004). NESB 
children's use of language may be different to that of English Speaking Background (ESB) children. ESB speakers may apply cultural congruence within the language interaction by respecting and responding to the intended meaning of NESB children's talk even when it is not grammatically correct (Gibbons, 2007).

Hawkins (2004) challenges researchers to use sociocultural theory within linguistically diverse educational settings to answer questions such as how NESB learners use strategies to interact with ESB learners and how ESB learners take up these opportunities or resist them. Our study draws on Hawkins' use of the guiding notions of community of learners/community of practice, ZPD, and multiple social languages to apply a sociocultural lens in the analysis of data from the interactions between ESB children and a NESB child.

\section{Research question}

This research aims to provide insight into how children from a Chinese speaking background (CSB) and ESB children understand each other and co-construct learning with varying amounts of teacher support within a New Zealand ECE learning context.

Research question: How does interaction occur in groups of children that include CSB and ESB children in an ECE environment?

\section{Method}

A qualitative single case study approach grounded in SCT (Vygotsky, 1978) was selected as the methodology to investigate a Chinese boy in a mainstream ECE Centre bounded by his interactions with ESB playmates. The data were gathered in Moana Kindergarten (pseudonym), a provincial, state ECE centre in New Zealand. Participants were Peter (pseudonym), a 3-year 3-month-old, New Zealand born Chinese boy from a Cantonese speaking background (CSB), and four ESB children, Michael, George, Elsa and Willis, who had interaction with him at playtime during data gathering. In addition, a researcher was present as a "participant observer" (Johnson \& Christensen, 2012, p. 209). This researcher was a teacher at Moana Kindergarten. She held the video camera and she occasionally interacted with the participants. The parents of the child participants provided information about their children and this added further insights into the background of each recorded episode.

\section{Ethical procedures}

Ethical approval was gained from Victoria University of Wellington Human Ethics Committee. The Head Teacher, the teaching staff and the parents of all the children at Moana Kindergarten gave informed consent. As the researcher-teacher had regular contact with participants outside of the study, she clarified that refusal or withdrawal from study participation would not affect the families' and children's involvement with ECE centre life. A full Cantonese translation of documents and communication was provided for Peter's parent. Since it was not feasible to seek written consent from the children, given their age, their informed assent was gained prior to recording by explaining the process in the children's home languages and inviting them to participate.

Collecting data from children requires the data collector's sensitivity towards children's emotional well-being (Mukherji \& Albon, 2014). Although the parents gave 
permission, the researcher-teacher was alert to the children's feelings and respected the possibility that they might not want to participate. This could have been expressed through children looking distressed, being disengaged in the play or behaving unusually. On those occasions, data collection ceased. For privacy protection, names of participants and the ECE centre were kept confidential.

\section{Data collection}

Peter and his peers were video-recorded on three consecutive Thursdays in June, 2015 at the same time of day for about five minutes during the routine free play times in normal ECE centre hours. This study maintains descriptive and interpretive validity by using excerpts of raw data from each episode as low-inference descriptors (Johnson \& Christensen, 2012).

Video-recording was used to capture verbal and nonverbal information that could be reviewed numerous times to refine the analysis (Penn-Edwards, 2012). However, as videodata provide only one "aspect of reality" (Penn-Edwards, 2012, p. 156), trustworthiness was increased though the use of a reflective journal. A slightly modified version of the Jefferson transcription system (Jefferson, 2004) was used for transcribing to include details of nonverbal as well as overlapping and paralanguage, such as intonation, gesture, and facial expression. Notes and documents from normal communication with the children's parents were used as well as general assessment documents such as learning stories to provide contextual background knowledge.

\section{Data analysis}

The video-recorded data were transcribed and then coded manually. This was a deductive, iterative process moving between key ideas or themes from Hawkins (2004), and between raw data and processed data (Creswell, 2012; Johnson \& Christensen, 2012). Coding was double-checked among the research team and some sections were re-coded to maintain intercoder reliability and consistency. Items relevant to social interaction were revealed by thematic coding: active interaction, emotion, influence and verbal interaction.

While the analytic process was flexible so as to include insights gained from the raw data (Corbin \& Strauss, 2015; Creswell, 2012), three guiding notions (Hawkins, 2004) were used to focus the process. They were: community of learners/community of practice, ZPD, and multiple social languages.

\section{Findings}

Three five-minute interactions between a CSB child and ESB children, labelled as Episodes One, Two and Three respectively, were transcribed and coded. The findings are explained episode by episode using key items arising from categorising line-by-line coding.

\section{Episode One}

\section{Participants}

Peter (CSB), Michael (ESB), George (ESB), Teacher/researcher (Japanese) 
Peter and Michael were playing near each other at one corner of the Duplo blocks area. Peter was holding a tractor with a trailer on which a white cubic block and a cone were mounted. Michael was lining up three different sized elephants near the table edge and holding one of them.

\section{Active interaction}

Some direct interactions were initiated by Peter. First, Peter's tractor very lightly touched Michael's elephant. Just before this happened, he had looked at Michael and checked his position. He chose to interact with Michael by very softly touching his toy:

Peter: ((looks towards Michael's chest for a moment, looks down at the tractor again and slows down. His tractor very lightly touches Michael's elephant=))

Michael: ((=[quietly moves one step away moving all three of his elephants]))

Michael communicated with Peter several times. When Peter took the block which Michael had just laid in front of him, Michael snatched it back and declared his intention orally:

Michael: ((quickly snatches the block off Peter and in a slow and normal tone, looking at Michael's car where several blocks are stacked)) That's mine...

When a similar incident happened later, he responded in a different way in spite of his wish to achieve the same outcome of getting his block back:

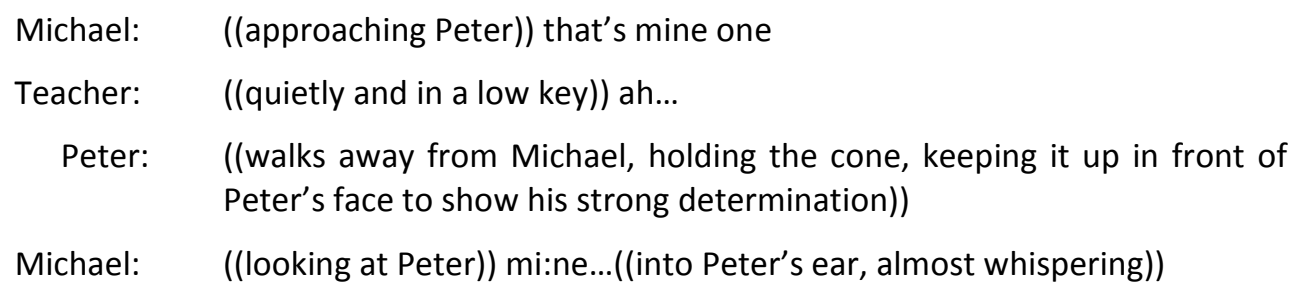

This time, Michael negotiated verbally instead of snatching. This choice may have been made as they developed more strategies for cooperation from the previous snatching incident.

\section{Emotion}

Peter's emotion was first expressed when the man came off Michael's elephant construction:

Michael: (([he places the man on the elephant again and looks at it from a lower angle (to check if it is firmly fixed?)]))

Peter: (llooks at his fixed elephant and man from a lower angle just like Michael did))

Michael: ((his facial expression significantly softens and he firmly sits another toy man on the remaining smallest elephant. Now, all three elephants have riders))

Peter stopped his construction, went closer and looked carefully at the fixed elephant. Empathy is seen here, as his action made Michael significantly soften his facial expression, looking as if he was warmed by how Peter had copied his action: 


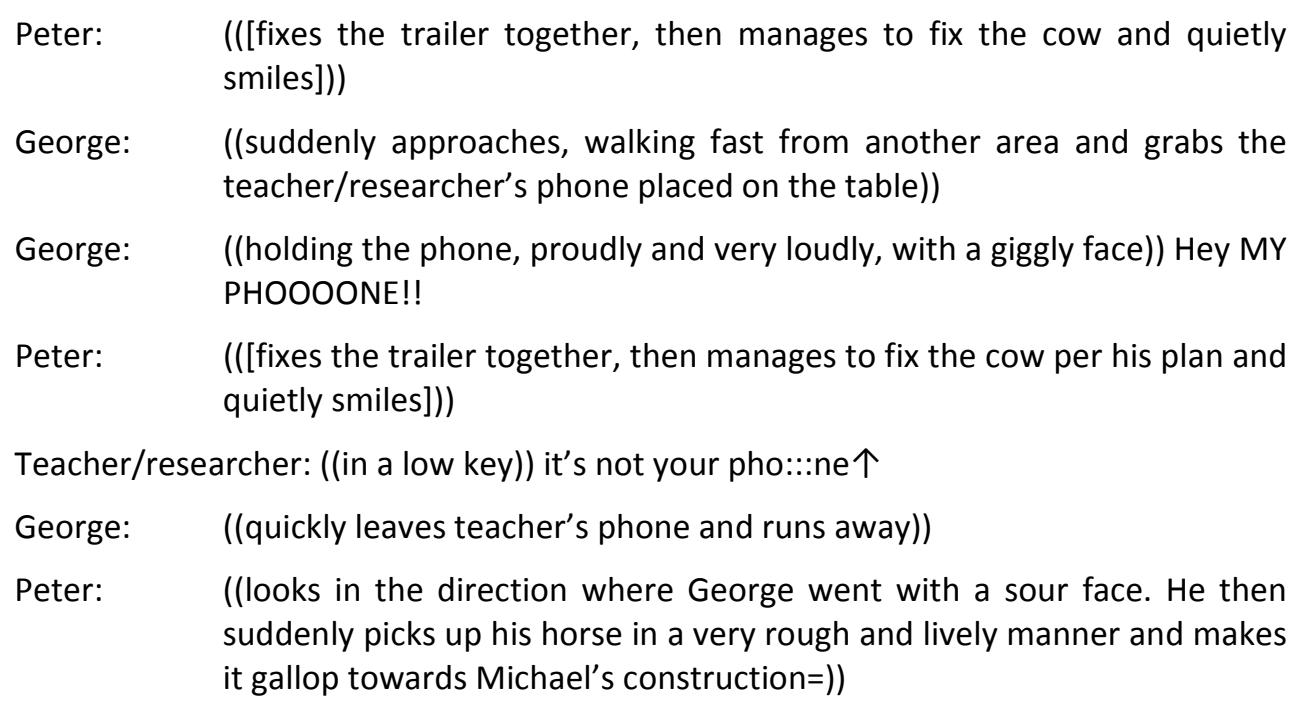

Although this incident was totally outside of the existing play context, a change in Peter's emotions occurred in response to George's sudden raid. Peter did not seem to pay too much attention to this, but he suddenly started using his toy in a very rough manner for the first time in this episode, as if his emotional mode synchronised with George's.

\section{Influence}

Peter's actions during his play sometimes changed in response to Michael's actions:

Michael: (([with a slightly satisfied look, gently manipulates the elephants and slowly walks them away from Peter in a careful and dramatic gesture]))

Michael's dramatic gesture had a role in play meta-communication, indicating that he had switched to imaginary mode. Although he did not clearly communicate with Peter, Peter naturally accepted this message and followed him soon after this.

\section{Episode Two}

\section{Participants}

Peter (CSB), Elsa (ESB), teacher/researcher (Japanese)

\section{Description of the play}

A concept box called 'GoGo Toys Balloons and Rings' and a wooden toy were placed on a small table in an open, inside area. The concept box is a counting, sorting a sequencing toy with pegs, rings and cards with brightly coloured balloons on them.

Peter and Elsa were standing next to each other, playing with the concept box together. Their movements were slow and relaxed, and no emotional tension was evident between them.

\section{Active interaction}

Peter and Elsa switched between cooperative play and parallel play, often sharing the same space. Active interaction occurred frequently as they shared the toy harmoniously. 
Peter and Elsa supported each other by offering turns and places:

Peter: ((picks another ring and places it on top of Elsa's. He then uses both hands and grabs a handful of the remaining rings. He places one, pauses, then drops one near Elsa.

Elsa: ((slightly smiles, quickly picks it up and adds it to the pole they were using.

Later, Elsa offered a balloon card to Peter so that he could finish a row. Both of them happily accepted each other's offer in reciprocal interaction. Elsa and Peter naturally interacted both verbally and non-verbally.

\section{Emotion}

The whole episode was carried out in a happy and pleasant atmosphere generated by both Peter and Elsa. His voice showed his delight when completing a pole. Peter appeared pleased when he learned something new from Elsa by observation:

Elsa: ((picks up a ring from the pole which was more than full)) hang on, this one.

Peter: ((observes))

((with an expression of delight, takes a ring from another pole))

\section{Influence}

When Peter and Elsa actively played together with a joint focus on the toy, their play influenced each other. Peter and Elsa sometimes started to compete to grab rings and place them on the poles more quickly than the other. When their arms crossed, they did not care and kept working quickly without conflict.

Just as Elsa seemed to inspire Peter in the way she played, Peter also showed leadership. When the poles were nearly full, he left Elsa with the rings task and started dismantling the area, soon joined by Elsa:

Peter: ((=starts mixing up the cards which had been neatly lined up))

Elsa: ((with a big smile, picks a ring and places it on another nearly-full tall pole))

Peter and Elsa: ((both smile and tidy all the cards away back into the stock area))

\section{Verbal interaction}

Peter was much more vocal than in the previous episode. He said "oh" to share his feeling of joy. He also sang a song in an unidentifiable language (neither Cantonese nor English) while he was playing, and made an unclear utterance while he was enjoying putting rings on a pole. He looked happy and relaxed when he was verbalising.

Elsa was the most vocal ESB child with Peter over the three episodes. She spoke naturally to Peter in a relaxed tone. She actively communicated her decisions, shared her experiences, made a suggestion, confirmed it, and expressed joy by giggling and singing. She also began to sing a song in an unidentifiable language soon after Peter started singing.

Elsa: hehhh ((giggling, lightly throwing the pole away in the stock)) I'm missing that all 
Elsa: ((wipes off rings left on the card rows, singing or chanting randomly)) La: lala, LA::::

These actions showed that their influence on one another was reciprocal.

\section{Episode Three}

\section{Participants}

Peter (CSB), Willis (ESB), teacher/researcher (Japanese)

\section{Description of the play}

Willis was playing alone quietly focusing on his Lego construction. Peter joined in and started his own construction copying what Willis was making.

\section{Active interaction}

Peter initiated active communication towards Willis in a respectful manner, by touching Willis with his car to show that he wanted to play with Willis.

\begin{tabular}{|c|c|}
\hline Peter: & $\begin{array}{l}\text { ((slowly and carefully flies his car down and lightly hits Willis's shoulder } \\
\text { with Peter's car)) }\end{array}$ \\
\hline Willis: & $(($ looks at Peter's car, then [touches his new car] )) \\
\hline Peter: & $(([$ flies his car back and quietly lands it on his Lego sheet $]))$ \\
\hline Willis: & ((quietly places his new car on the wide edge of his sheet)) \\
\hline Peter: & $\begin{array}{l}\text { ((slowly drives his car again, from the middle of his sheet, over the edge } \\
\text { of the table, directly towards Willis's sheet)) }\end{array}$ \\
\hline Willis: & $\begin{array}{l}\text { ((holds his new car part up and feels around it as if checking how firmly } \\
\text { parts are attached)) }\end{array}$ \\
\hline Peter: & $\begin{array}{l}\text { ((as his car reaches the edge of Willis's sheet, stops his car on this kerb } \\
(0.2) \text { leaves the car there and makes a funny quick motion as if punching } \\
\text { or fighting)) }\end{array}$ \\
\hline
\end{tabular}

Peter used various strategies to communicate with Willis such as initiating physical contact, making contact using a toy, waiting for a response, and drawing attention using funny gestures.

Although Willis did not reciprocate, Peter succeeded in receiving a clear positive response from Willis on his second attempt when Willis was going away from the area:

Peter: $\quad(($ makes a gun shape with his right hand, follows Willis and lightly pats his back.))

Wills: $\quad$ ((turns around and looks at Peter $))=$

Peter: $\quad=(($ walks backward back to the Lego area, looks at Willis's sheet, points at it and bends down to look into it as he reaches the area. He moves back towards his sheet, then quickly moves back to Willis's sheet))(0.2)

Peter: ((picks up some car blocks from the pile and gives them to Willis))

Willis: ((still looking in another direction)) 
Peter: $\quad$ ((showing the blocks in front of Willis)) that O:::Ne!

Willis: ((his hood moves as Peter's block touches it. He turns around))

Peter: ((slightly moving back to give space, still showing his block)) That one.

Willis: ((with a gentle smile, looks at Peter's offer))

Peter: $\quad$ ((softly hands his blocks to Willis))

Willis: $\quad(($ accepts the blocks $))=$

Peter: $\quad=(($ turns around and heads off to his work area $))$

Willis: ( (a little shyly follows Peter, then stops to get some more blocks from the pile))

Peter: ((standing by the work table, in between Peter's and Willis's sheets, looking straight at Willis)) ((happily singing, sounding like English or Maori, unidentifiable))

In this example, Peter succeeded in motivating Willis to stay in the same area with him by developing strategies from patting his shoulder, going back to the Duplo work area, confirming if Willis was coming back, and then going back to Willis to offer a block. When Willis accepted his offer, Peter confidently went back to the area followed by Willis and happily sang a song.

\section{Emotion}

As in the example above, Peter expressed happiness when playing together with Willis. Right after singing happily, he went back to his own construction, smiling. He also showed excitement when participating in Willis's imaginary play, flying and landing vehicles:

Peter: $\quad$ ((pointing at the centre of his sheet)) YE:::::::::! ((then puts his hand up as if an airplane is taking off) $)=$

On the other hand, Willis's emotion was difficult to interpret, although he looked calmly settled in his construction work most of the time, apart from occasionally proudly showing his work to the teacher. However, he gently smiled once when Peter offered a block to him.

\section{Influence}

Peter spent sustained time in a parallel play mode working on his own construction inspired by Willis. Also, Willis used play meta-communication to switch from construction into imaginary play followed by Peter doing imaginary play as well:

Willis: ((as the blocks are firmly attached, holds the car up high above his head with a flying motion))

Willis: ((comes back to his work table with the motion of flying his car))

\section{Verbal interaction}

Although the type of play was similar to the Duplo play in Episode One, Peter was much more vocal this time:

Peter: $\quad$ ((picks a block from the pile)) WA! 
The above utterance seemed like playful paralanguage whereas the following utterances are onomatopoeia representing a car, punching, and a shooting gun, respectively:

$\begin{array}{ll}\text { Peter: } & \text { Woo::: (([flies his car over Willis's sheet, near his constructed car])) } \\ \text { Peter: } & \text { ((slowly driving his car towards Willis's direction)) Pshhhh!! ((making a } \\ & \text { noise similar to a sound effect for punching or gun shooting in films)) } \\ \text { Peter: } & \begin{array}{l}\text { ((takes his car to the dark triangular tunnel space of the nearby easel, } \\ \text { points his car as if using a gun)) Vavavavavavavava. }\end{array}\end{array}$

Although, Willis did not speak once to Peter, this did not create an atmosphere of excluding Peter.

\section{Discussion}

The children's interactions are analysed based on three of the guiding notions suggested by Hawkins (2004). These are: community of learners/community of practice, ZPD/scaffolding, and multiple social languages.

\section{Community of practice/community of learners}

Key to forming a community of practice in ECE is a holistic approach to caring for a child (Ministry of Education, 2017). This involves engagement, imagination, a sense of belonging, warm/positive relationships, respect, and learning from/with each other (Bredekamp, 2014; Wenger, 1998). The development of a community of practice was evident. Even when the children were not actively talking with each other, their presence and play influenced each other. Their play switched between parallel and cooperative play depending on the degree of interaction they had.

Although children from minority language groups may sometimes have difficulty in communicating in a way congruent to the dominant culture and language (Barnard, 2009; Han, 2009), this was not evident during these three episodes. Each episode included only a small group of children and the play resources did not appear culturally specific. Since it is beneficial for bilingual children to apply knowledge acquired in their first language in an English speaking environment (Akbulut, 2007), such universally appealing resources seemed to facilitate the development of Peter's skills and confidence (Smith, 2012). A common enterprise in which resources were shared was generated by teacher planning for sustained play where all the children in the group were actively participating in the community. In addition, the teacher stood back to allow the children to lead and interact actively which enabled them to establish trustful relationships with each other (White et al., 2010).

\section{ZPD/scaffolding}

On different occasions both Peter and his play partners were observed scaffolding each other. Such scaffolding is successful when a learner has a trustful relationship and a sense of belonging (Barnard, 2009; Davies, 2004). Collaborative scaffolding was also evident, for example, in Episode Two, Peter and Elsa helped, influenced, and learnt from each other while playing collaboratively. Peter also appeared to learn from Willis through observation in 
parallel play (Lim, 2012). In Episode Three, the presence of Willis seemed to provide emotional scaffolding to anchor Peter in the play area. Peter's wish to stay with Willis was evident in his asking Willis to come back to play.

Above all, children's mutual support was effective in that it was at the right level (Hammond \& Gibbons, 2006) and the solution was understandable for the learner (Wood et al., 1976). In addition, children may choose to recognise and make use of peer knowledge at times during play. Such free choice in seeking support may be maximised by a relatively equal power balance between peers, as children may follow the lead of a more powerful individual, such as a teacher, rather than critically thinking of their actual needs (Zang, 2009). Teachers may decide to interrupt children earlier than desirable (Broadhead, 2009), yet children may accept this direction because they see teachers as being in authority (Zang, 2009). From this viewpoint, peer scaffolding may be invaluable in supporting knowledge co-construction (Walqui, 2006).

\section{Multiple social languages}

As also observed by Hojnoski et al. (2008), the children in this study spent most of the time in silence. However, these children actively interacted with each other using nonverbal language with some significant verbal communication. The participating children seemed to choose their mode of communication depending on their relationship with the interlocutor (Wells, 2009), and the purpose of and the context in which they were interacting (Martin, 2009).

Emotional synchronisation led children to agree on a common way to play or interact (Imai, 2010). Children carefully observed each other and chose social strategies suitable for the peer. Co-construction of emotion among learners (Imai, 2010; Swain, 2013) was seen also in Episode Two. Both Elsa and Peter sang random songs at the same time that did not contain comprehensible language.

The children engaged in imaginary play and switched their play between construction and dramatic play. They used toys to communicate their intention to play together in their imaginative play.

\section{Conclusion}

While this study is a single case study with a small number of participants in a particular education setting, the findings provided evidence that interaction among linguistically diverse children occurred using both verbal and non-verbal language. The children interacted by observing and acknowledging each other. Both the CSB child and the ESB children actively led, supported, and influenced each other, co-constructing knowledge and skills within their community of practice as they shared common tasks and/or resources.

This study argues for the importance of providing sufficient free playtime in an ECE environment that includes linguistically diverse learners. Peer interaction provides different learning opportunities to those that adult teachers provide, as children may have different perspectives to those of the adults. By allowing children to develop a community of practice with their peers, children achieve a sense of belonging.

Although play is recognised and valued in children's learning (Jamison et al., 2012; Ministry of Education, 1996), teachers face increasing pressure to be accountable for children's school readiness and as a result, the time children spend in child-oriented free play 
is decreasing (Nicolopoulou, 2010). However, the findings of this study support the importance of free play for a NESB child as an emergent bilingual.

This study demonstrates the importance and effectiveness of peer interaction and coconstruction of learning through peer collaboration. NESB children are regarded as priority learners (Education Review Office, 2015) for whom teachers are expected to develop specific strategies. This study suggests that if a teacher observes and waits before intervening, both ESB and CSB children have opportunities to negotiate meaning with one another through play. Further longitudinal research in the interaction among NESB and ESB children would contribute further understanding of the conditions that promote emergent bilingualism in ECE settings.

\section{References}

Akbulut, Y. (2007). Bilingual acquisition and cognitive development in early childhood: Challenges to the research paradigm. Elementary Education Online, 6, 422-429.

Aukrust, V., \& Rydland, V. (2011). Preschool classroom conversations as long-term resources for second language and literacy acquisition. Journal of Applied Developmental Psychology, 32, 198-207.

Barnard, R. (2009). Submerged in the mainstream? A case of an immigrant learner in a New Zealand primary school classroom. Language and Education, 23, 233-248.

Bodrova, E. (2008). Make-believe play versus academic skills: A Vygotskian approach to today's dilemma of early childhood education. European Early Childhood Education Research Journal, 16, 357-369.

Bredekamp, S. (2014). Effective practices in early childhood education: Building a foundation ( $2^{\text {nd }}$ ed.). London: Pearson.

Broadhead, P. (2009). Conflict resolution and children's behaviour: Observing and understanding social and cooperative play in early years educational settings. Early Years: An International Research Journal, 29, 105-118.

Carr, M. (2009). Kei tua o te pae: Assessing learning that reaches beyond the self and beyond the horizon. Assessment Matters, 1, 20-46.

Castro, D. (2014). The development and early care and education of dual language learners: Examining the state of knowledge. Early Childhood Research Quarterly, 29, 693-698.

Castro, D., Páez, M., Dickinson, D., \& Frede, E. (2011). Promoting language and literacy in young dual language learners: Research, practice, and policy. Child Development Perspectives, 5, 15-21.

Cho, R. (2012). Are there peer effects associated with having English language learner (ELL) classmates? Evidence from the early childhood longitudinal study kindergarten cohort (ECLS-K). Economics of Education Review, 31(50), 629-643.

Corbin, J., \& Strauss, A. (2015). Basics of qualitative research: Techniques and procedures for developing grounded theory ( $4^{\text {th }}$ ed.). London: Sage.

Creswell, J. (2012). Educational research: Planning, conducting, and evaluating quantitative and qualitative research ( $4^{\text {th }}$ ed.). Boston, MA: Pearson.

Davies, S. (2004). Barriers to belonging: Students' perceptions of factors which affect participation in schools. In J. T. Wearmouth, T. Glynn,R. Richmond, \& M. Berryman (Eds.), Inclusion and behaviour management in schools: Issues and challenges (pp. 322-340). London, UK: David Fulton. 
Ebbeck, M., \& Waniganayake, M. (2010). Perspective on play in a changing world. In M. Ebbeck \& M. Waniganayake (Eds.), Play in early childhood education: Learning in diverse contexts (pp. 5-25). South Melbourne, Victoria: Oxford University Press.

Education Review. (2015). Priority learners. Retrieved from http://www.ero.govt.nz/publications/he-pou-tataki-how-ero-reviews-earlychildhood-services/part-2-outcomes-for-children-in-early-childhood-education/

Farnsworth, M. (2012). Who's coming to my party? Peer talk as a bridge to oral language proficiency. Anthropology and Education Quarterly, 43, 253-270.

Fleer, M. (2013). Collective imagining in play. In I. Schousboe \& D. Winther-Lindqvist (Eds.), Children's play and development: International perspectives on early childhood education and development (pp. 73-87). Netherlands: Springer.

Gibbons, P. (2007). Mediating academic language learning through classroom discourse. In J. Cummins \& C. Davison (Eds.), International handbook of English language teaching (pp. 701-718). New York, NY: Springer.

Gibbons, P. (2015). Scaffolding language, scaffolding learning: Teaching English language learners in the mainstream classroom ( $2^{\text {nd }}$ ed). Portsmouth, $\mathrm{NH}$ : Heinemann.

Gottfried, M. (2014). The positive peer effects of classroom diversity: Exploring the relationship between English language learner classmates and socioemotional skills in early elementary school. The Elementary School Journal, 115, 22-48.

Hammond, J., \& Gibbons, P. (2006). What is scaffolding? In J. Hammond (Ed.), Scaffolding: Teaching and learning in language and literacy education (pp. 1-14). Newtown, NSW: PETA.

Hawkins, M. (2004). Researching English language and literacy development in schools. Educational Researcher, 33, 14-25.

Han, H. (2009). Sociocultural influence on children's social competence: A close look at kindergarten teachers' beliefs. Journal of Research in Childhood Education, 24, 80-96.

Hojnoski, R., Margulies, A. S., Amberly, B., Bose-Deakins, J., \& Sumara, K. M. (2008). Analysis of two early childhood education settings: Classroom variables and peer verbal interaction. Journal of Research in Childhood Education, 23, 193-209.

Horwitz, E. K. (2010). Foreign and second language anxiety. Language Teaching, 43, 154-167. Howard, J. (2009). Pride and prejudice... and other barriers to teaching for Asian New Zealanders. Asia Pacific Journal of Education, 29, 143-157.

Iddings, A. C., \& Jang, E. Y. (2008). The mediational role of classroom practices during the silent period: A new-immigrant student learning the English language in a mainstream classroom. TESOL Quarterly, 42, 567-590.

Imai, Y. (2010). Emotions in SLA: New insights from collaborative learning for an EFL classroom. Modern Language Journal, 94, 278-292.

Jamison, K., Forston, L. D., \& Stanton-Chapman, T. L. (2012). Encouraging social skill development through play in early childhood special education classrooms. Young Exceptional Children, 15, 3-19.

Jefferson, G. (2004). Glossary of transcript symbols with an introduction. In G. H. Lerner (Ed.), Conversation analysis: Studies from the first generation (pp. 13-31). Philadelphia, PA: John Benjamins.

Johnson, B., \& Christensen, L. (2012). Educational research: Quantitative, qualitative, and mixed approaches ( $4^{\text {th }}$ ed.). London, UK: Sage.

Krashen, S. (1981). Second language acquisition and second language learning. London: Pergamon. 
Lave, J., \& Wenger, E. (1991). Situated learning: Legitimate peripheral participation. Cambridge, UK: Cambridge University Press.

Lee, W., \& Carr, M. (2012). Learning stories: Constructing learner identities in early education. London: Sage.

Lim, E. (2012). Patterns of kindergarten children's social interaction with peers in the computer area. Computer-Supported Collaborative Learning, 7, 399-421.

Liu, E., Lin, C., Liou, P., Feng, H., \& Hou, H. (2013). An analysis of teacher-student interaction patterns in a robotics course for kindergarten children: A pilot study. The Turkish Online Journal of Education Technology, 12, 9-18.

MacNaughton, G., \& Williams, G. (2008). Techniques for teaching young children: Choices in theory and practice ( $3^{\text {rd }}$ ed.). French's Forest, NSW: Pearson.

Martin, J. R. (2009). Language, register and genre. In C. Coffin, K. Lillis, \& K. A. O’Halloran (Eds.), Applied linguistics methods: A reader (pp. 12-32). London: Routledge.

Ministry of Education. (1996). Te whāriki: He whàriki màtauranga mò ngà mokopuna o Aotearoa: Early childhood curriculum. Wellington: Learning Media.

Ministry of Education. (2017). Te Whāriki: He whāriki mātauranga mō ngā mokopuna o Aotearoa. Wellington: Ministry of Education.

Mukherji, P., \& Albon, D. (2014). Research methods in early childhood: An introductory guide $\left(2^{\text {nd }}\right.$ ed.). London: Sage.

Nicolopoulou, A. (2010). The alarming disappearance of play from early childhood education. Human Development, 53, 1-4.

O'Connor, D., \& Angus, J. (2014). Give them time: An analysis of school readiness in Ireland's early education system: A Steiner Waldorf perspective. International Journal of Primary, Elementary and Early Years Education, 42, 488-497.

Penn-Edwards, S. (2012). Human factors affecting the use of video recording methodology in qualitative research. International Journal of Multiple Research Approaches, 6, 150159.

Purcell-Gates, V., Melzi, G., Najafi, B., \& Orellana, M. F. (2011). Building literacy instruction from children's sociocultural worlds. Child Development Perspectives, 5, 22-27.

Smith, P. (2012). Children as teachers: Creating opportunities for children to share expertise with their peers. New Zealand Research in Early Childhood Education, 1, 84-101.

Swain, M. (2013). The inseparability of cognition and emotion in second language teaching. Language Teaching, 46, 195-207.

Van Hoorn, J., Nourot, P. M., Scales, B., \& Alward, K. R. (2011). Play at the center of the curriculum ( $5^{\text {th }}$ ed). Upper Saddle River, NJ: Pearson.

Vygotsky, L. (1978). Mind in society. Cambridge, MA: Harvard University Press.

Walqui, A. (2006). Scaffolding instruction for English language learners: A conceptual framework. International Journal of Bilingual Education and Bilingualism, 9, 159-180.

Walqui, A., \& van Lier, L. (2010). Scaffolding the academic success of adolescent English language learners: A pedagogy of promise. San Fransisco: WestEd.

Wells, G. (2009). The meaning makers: Learning to talk and talking to learn. Buffalo, NY: Multilingual Matters.

Wenger, E. (1998). Communities of practice: Learning, meaning, and identity. Cambridge, MA: Cambridge University Press.

White, J., Ellis, F., O'Malley, A., Rockel, J., Stover, S., \& Toso, M. (2010). Play and learning in Aotearoa New Zealand early childhood education. In I. Pramling-Samuelsson \& 
M. Fleer (Eds.), Play and learning in early childhood settings: International perspective (pp. 19-50). London: Springer.

Wood, D., Bruner, J. S., \& Ross, G. (1976). The role of tutoring in problem solving. Journal of Child Psychology and Psychiatry, 17, 89-100.

Zang, W. (2009). On power relation in the design of language research project and the analysis of data. English Language Teaching, 2, 171-174.

Madoka Takemoto is currently undertaking an Education Doctorate at Victoria University. She is a qualified early childhood teacher, teaching in a multicultural kindergarten in New Zealand.

Email: madoka.takemoto@vuw.ac.nz

Carolyn Tait is a senior lecturer in the School of Education. She teaches in initial teacher education courses and works with experienced teachers to increase their knowledge and skills in teaching linguistically diverse students.

Email: carolyn.tait@vuw.ac.nz

Margaret Gleeson is a senior lecturer in the School of Education. Her research field and teaching area is educational linguistics and initial teacher education. She works with teachers to support emergent bilingual learners in mainstream classes.

Email: margaret.gleeson@vuw.ac.nz

\section{Funding}

This research received no specific grant from any funding agency in the public, commercial, or not-for-profit sectors. 